
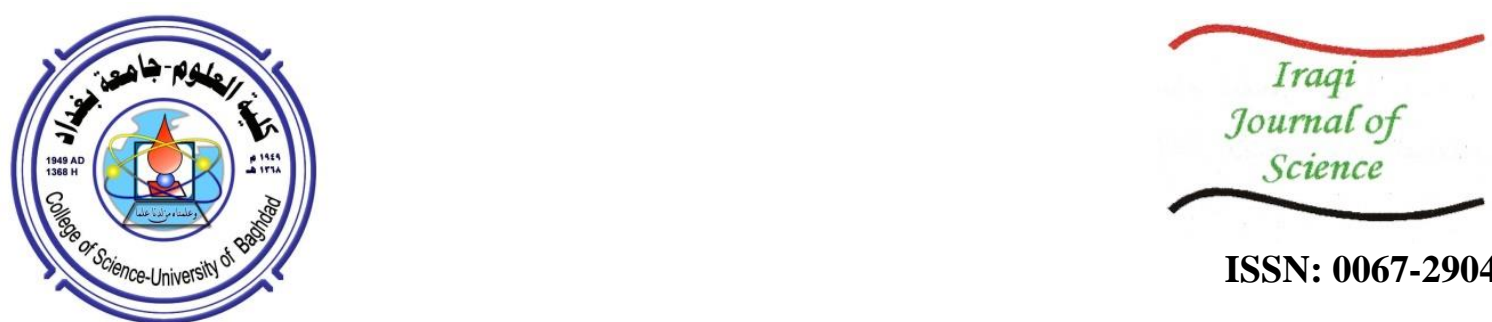

ISSN: 0067-2904

\title{
Hydrochemical Evaluation of Groundwater from Selected Wells in Al Muthana Governorate, Southern Iraq
}

\author{
Raad Al- Khafaji ${ }^{1}$, Saad Muhi ${ }^{2}$, Adnan Jassam ${ }^{3}$ \\ ${ }^{1}$ Department of Biology, College of Education for Pure sciences (Ibn Al-Haitham), University of Baghdad, \\ Baghdad, Iraq \\ ${ }^{2}$ Department of Geology, College of Science, University of Baghdad, Baghdad, Iraq \\ ${ }^{3}$ Department of Biology, College of Education, Iraqia University, Baghdad, Iraq
}

Received: 5/6/2020

Accepted: 29/9/2020

\begin{abstract}
The study area is part of the city of Samawa in Al Muthanna Governorate in southern Iraq. The study area is located to the west of Samawa city bounded by the north latitudes $31^{\circ} 11^{\prime}-31^{\circ} 42^{\prime}$ and east longitudes $44^{\circ} 58^{\prime}-45^{\circ} 16^{\prime}$ and its groundwater resources are developed for supply and irrigation purposes. In order to evaluate the quality of groundwater in the study area, twenty three groundwater samples were collected and analyzed for physical and chemical parameters. Hydrochemical analysis showed that the groundwater of the study area is excessively mineralized and very hard. The increase in flow length of groundwater in the study area caused a change in water quality from bicarbonate to sulfate and chloride. The abundance of the major ions is as follows: $\mathrm{SO}_{4}>\mathrm{CL}>\mathrm{HCO}_{3}>\mathrm{NO}_{3}$ and $\mathrm{Na}>\mathrm{Ca}>\mathrm{Mg}>\mathrm{K}$. The dominant type of groundwater is $\mathrm{Na}^{+}$- sulfate. The water of the studied wells is not suitable for human drinking. Depending on TDS and EC values, most samples of the water are moderate saline class for irrigation. Most wells are good to permissible (wells No.4,14,17) and doubtful (well No. 12) for irrigation depending on $\mathrm{Na} \%$, while unsuitable for irrigation depending on EC (except well No. 17 which is permissible). Excellent water class (S1)for agriculture was recorded depending on SAR, except for well N0.2 which had an a good class (S2).
\end{abstract}

Keywords: Water type, groundwater, irrigation water, chemical formula.

\section{تقييم هايدروكيميائي للمياه الجوفية لآبار مختارة من محافظة المثنى,جنوب العراق}

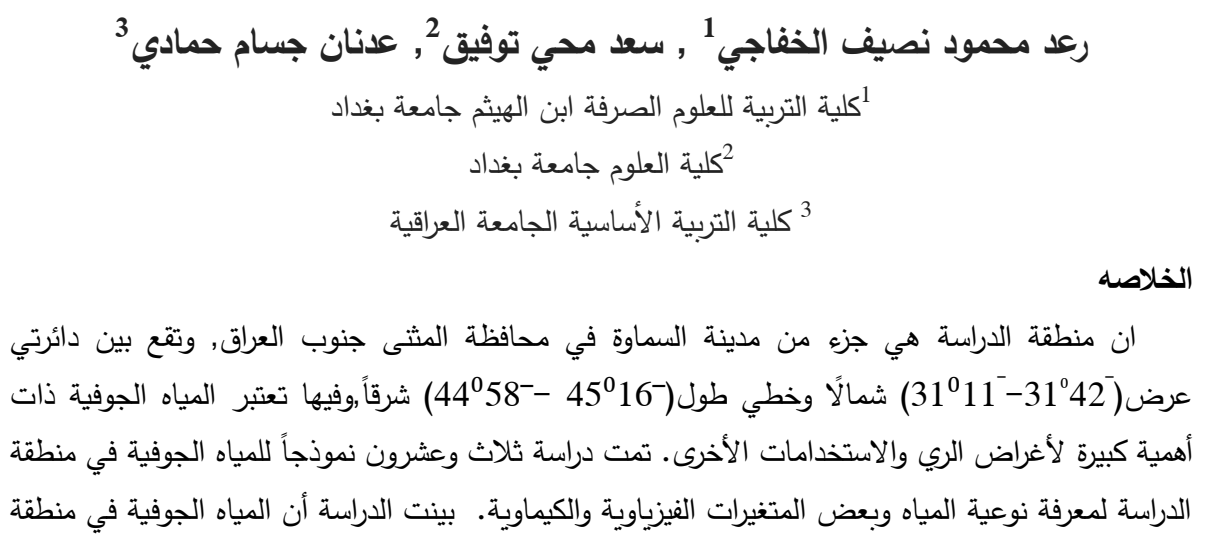




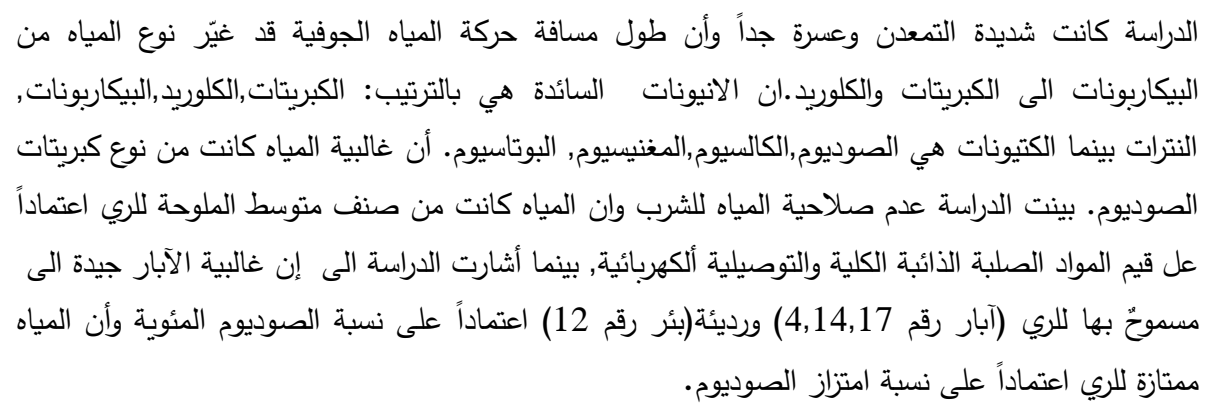

\section{1: Introduction}

The hydrogeological studies are considered as an important task in regions where groundwater is the only source of water, which is used for various purposes, particularly in agriculture .Therefore, the decline in the quality of groundwater occurs as a result of increasing salinity in the soil. The objectives of this research are: a- studying the hydro chemical properties of groundwater, bdetermination of the quality of groundwater, $c$ - determination of the validity of groundwater for different uses by comparing with the Iraqi and global specifications.

\section{1-1: Study Area}

The study area is located to the southern part of Iraq within Al Muthana governorate to the west of the city of Samawa and to the south of Sawa Lake, bounded by the north latitudes $31^{\circ} 11^{\prime}-31^{\circ} 42^{\prime}$ and east longitudes $44^{0} 58^{\prime}-45^{\circ} 16^{\prime}$ (Figure-1). The study area and the surroundings are entirely covered by sedimentary rocks of Cenozoic Era, ranging in age from Early Eocene up to recent Quaternary sediment. Lithologically, the following stratigraphic sequence exists:

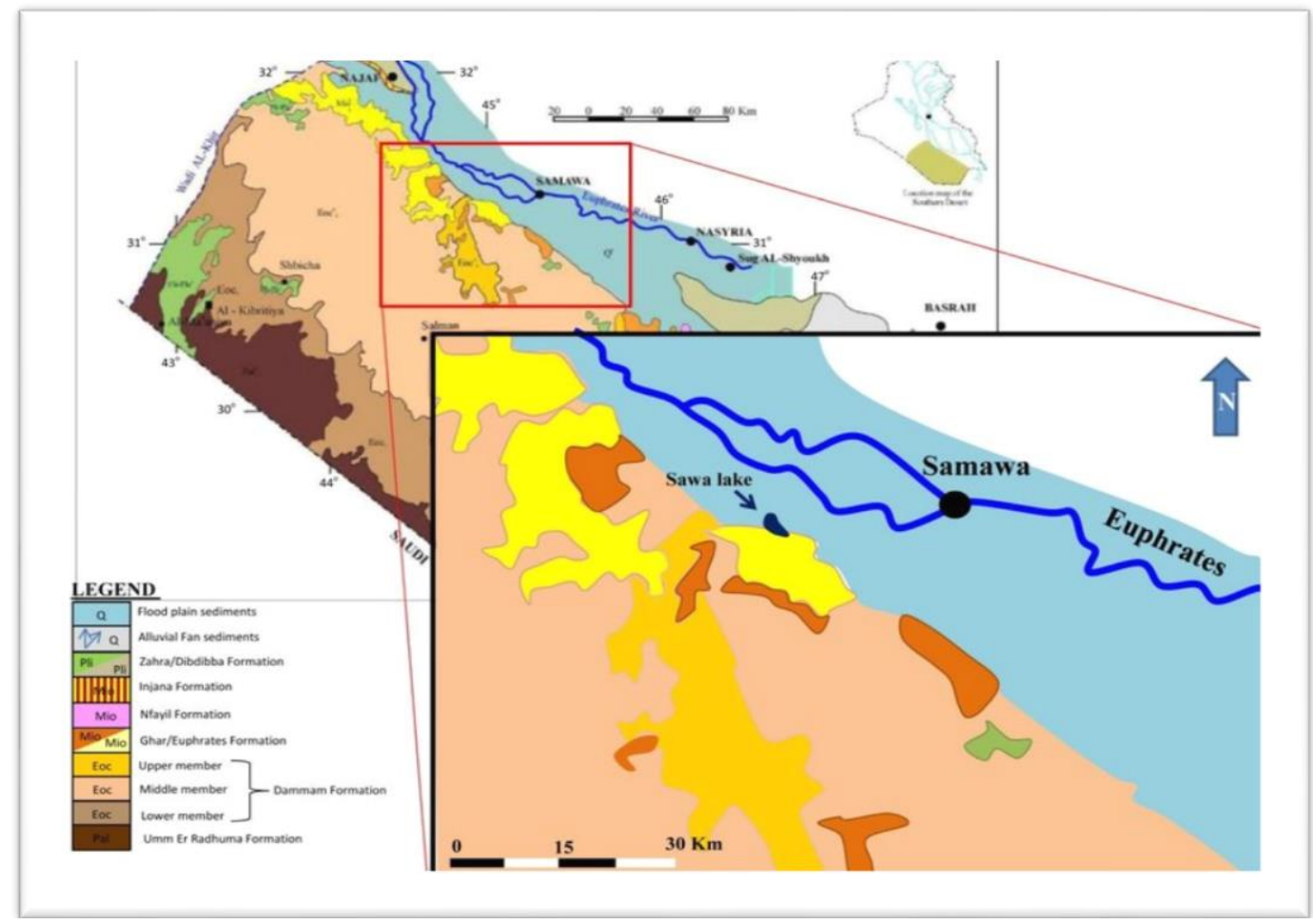

Figure 1-Geological map of the study area [1]

1-Rus formation (Early Eocene): The Rus formation corresponds to beds previously assigned to the Dammam formation [2].It comprises recrystallized limestone, which is partly silicified. In the Mesopotamian zone of south Iraq, the formation consists predominantly of anhydrite with some unfossiliferous limestone, blue shale and marl [3]. The formation is not exposed in the study area.

2-Dammam formation (Middle-Late Eocene):It is the only exposed formation of paleogene Epoch in the study area. It is comprised of limestone, dolomite, marl, and shale. Dammam formation is deposited in the carbonate inner shelf lagoon and shoal [2]. 
3- Euphrates formation (Early Miocene): The formation is composed of shelly, chalky, well bedded, recrystallized limestone[4].The geological conditions of this formation, represented by the abundance of openings and interstitial spaces as a result of the dissolution of limestone, contributed to the formation of this reservoir as an important groundwater reservoir.

4- Nafayil formation (Middle Miocene) : The section of Nafayil formation is of a composite type. The lower member is in Garat Nafayil south of Haditha, whereas the upper member is exposed at $3 \mathrm{~km}$ to the west of Al-Habbania lake. The lower member of Nafayil formation is exposed in the study area in a limited location, forming Mesas and small spots that overly Euphrates formation to the east of Sawa Lake. Only the lower member of the Nafayil formation, which consists of cyclic deposits, is exposed in the study area.

5- Quaternary sediments: The quaternary deposits consist of the sediments of the plaiostocene and the Holocene. These deposits cover the study area, which are marine, river and air sediments, and their thickness ranges between 140-200 meters. These sediments are characterized by their high permeability that helps to filter surface water to the underground layers that can be reservoirs of groundwater.

\section{1-2: Materials and Methods}

The physical and chemical data for twenty three wells in Samawaharea(Figure-2,Table-1) were taken from General Commission for Groundwater and included measurements of cations $\left(\mathrm{K}^{+}, \mathrm{Na}^{+}\right.$ $\left., \mathrm{Mg}^{+2}, \mathrm{Ca}^{+2}\right)$ and anions $\left(\mathrm{CL}^{-}, \mathrm{SO}_{4}^{-2}, \mathrm{HCO}_{3}^{-}, \mathrm{NO}_{3}^{-}\right)$as well as hydrogen ion concentration $(\mathrm{PH})$, electrical conductivity (EC), and total dissolved solids(TDS)(Table-2).

The samples of water were collected in September 2014 (water deficit period). The samples were placed in plastic bottles with a volume of 1.5 liter after washing by distilled water and then rinsed by sample water for each well to ensure the elimination of pollutants. $\mathrm{pH}$ and $\mathrm{EC}$ were measured in the site after collecting the samples using calibrated EC-pH meter with a standard solution, while TDS was measured by the evaporation method. Water samples were analyzed to determine ions concentration in the laboratories of General Commission for Groundwater.

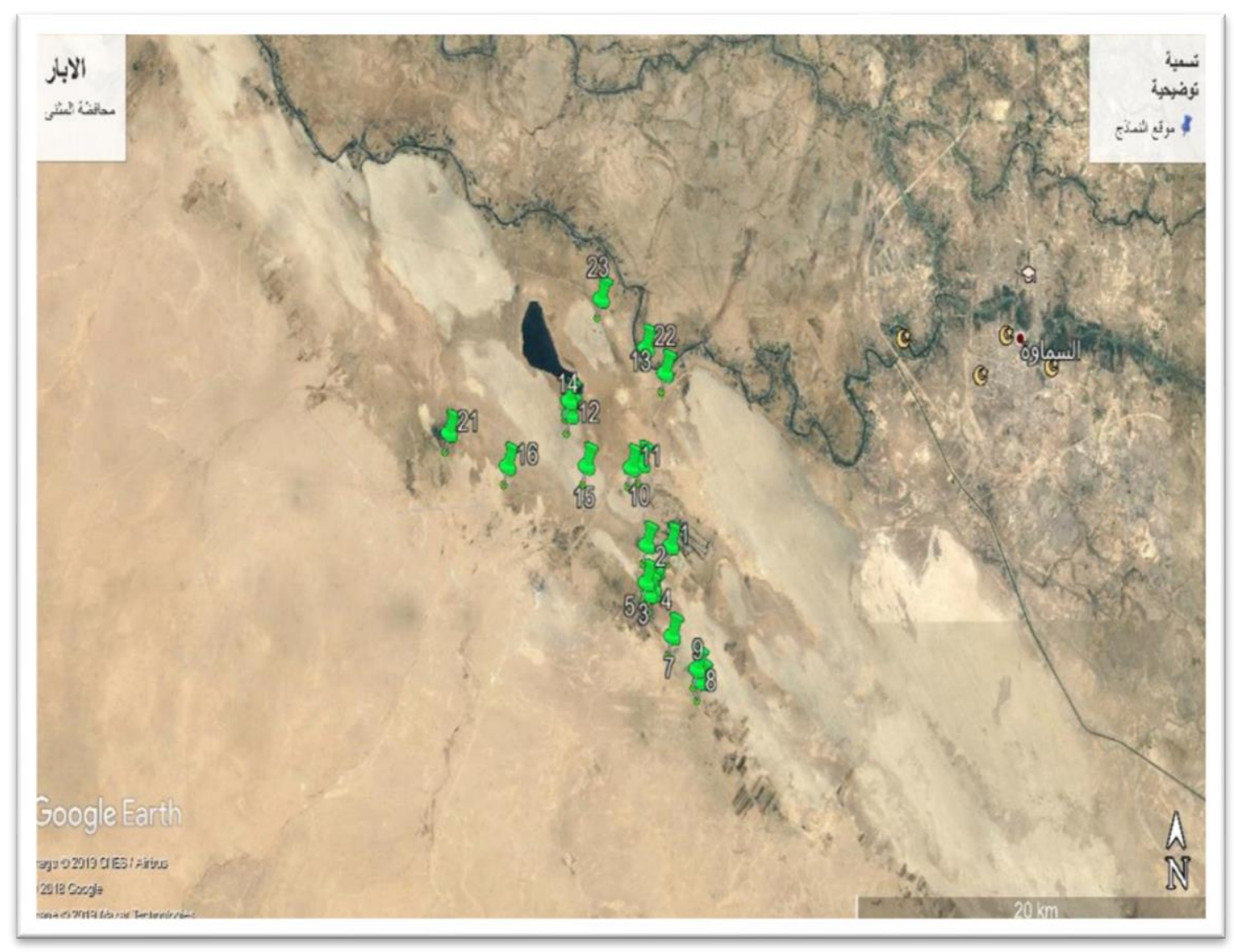

Figure 2-Location map showing sampling sites 
Table 1-Groundwater samples and their coordinates

\begin{tabular}{|c|c|c|c|c|c|}
\hline Well no. & Location name & District & Well Depth & $\begin{array}{c}\text { Geo-x } \\
\text { (Latitude) }\end{array}$ & $\begin{array}{c}\text { Geo-y } \\
\text { (Longitude) }\end{array}$ \\
\hline 1 & $\begin{array}{c}\text { Mamlaht } \\
\text { Alsamawa/3 }\end{array}$ & Al Salman & 65 & $45^{0} 04^{\prime}$ & $31^{0} 14^{\prime}$ \\
\hline 2 & $\begin{array}{l}\text { Abd Alhadi } \\
\text { Shageel }\end{array}$ & Al Salman & 56 & $45^{\circ} 03^{\prime}$ & $31^{0} 14^{\prime}$ \\
\hline 3 & $\begin{array}{c}\text { Mohamed } \\
\text { Sabaa Banian }\end{array}$ & Al Salman & 73 & $45^{\circ} 03^{\prime}$ & $31^{0} 13^{\prime}$ \\
\hline 4 & Ean Algathari & Al Salman & 6 & $45^{0} 04^{\prime}$ & $31^{0} 13^{\prime}$ \\
\hline 5 & $\begin{array}{c}\text { Salem Sharaa } \\
\text { Mohamed }\end{array}$ & Al Salman & 20 & $45^{0} 0359^{\prime \prime}$ & $31^{0} 13^{\prime} 06^{\prime \prime}$ \\
\hline 6 & $\begin{array}{c}\text { Raheem Sharaa } \\
\text { Mohamed }\end{array}$ & Al Salman & 75 & $45^{0} 03$ & $31^{0} 13^{\prime}$ \\
\hline 7 & $\begin{array}{c}\text { Fares Zmeait } \\
\text { Khwelan }\end{array}$ & Al Salman & 40 & $45^{0} 04^{\prime}$ & $31^{0} 12^{\prime}$ \\
\hline 8 & $\begin{array}{c}\text { Khaled Saud } \\
\text { Ali Anad }\end{array}$ & Al Salman & 90 & $45^{0} 05^{\prime} 32^{\prime \prime}$ & $31^{\circ} 1127^{\prime \prime}$ \\
\hline 9 & $\begin{array}{l}\text { Ayed Sajet } \\
\text { Musa/1 }\end{array}$ & Al Salman & 94 & $45^{\circ} 05^{\prime} 40^{\prime \prime}$ & $31^{\circ} 11^{\prime} 11^{\prime \prime}$ \\
\hline 10 & $\begin{array}{c}\text { Bakan Shalaga } \\
\text { Abu Algeg }\end{array}$ & Al Salman & 55 & $45^{\circ} 0337^{\prime \prime}$ & $31^{\circ} 1553^{\prime \prime}$ \\
\hline 11 & $\begin{array}{c}\text { Kayfya Hamed } \\
\text { Abu Algeg }\end{array}$ & Al Salman & 80 & $45^{\circ} 03^{\prime} 15^{\prime \prime}$ & $31^{\circ} 15^{\prime} 49^{\prime \prime}$ \\
\hline 12 & $\begin{array}{c}\text { Magayer Abadi } \\
\text { Manfi }\end{array}$ & Al Healal & 45 & $45^{\circ} 01^{\prime}$ & $31^{\circ} 17^{\prime}$ \\
\hline 13 & Ayoub Shadad & Al Salman & 60 & $45^{\circ} 04^{\prime}$ & $31^{\circ} 17^{\prime}$ \\
\hline 14 & $\begin{array}{c}\text { Mahmeat Sawa } \\
\text { Altabiaea/1 }\end{array}$ & Al Healal & 40 & $45^{\circ} 01^{\prime}$ & $31^{\circ} 16^{\prime}$ \\
\hline 15 & $\begin{array}{l}\text { Hazim Karem } \\
\text { Lazam }\end{array}$ & Al Salman & 50 & $45^{\circ} 01^{\prime}$ & $31^{\circ} 15^{\prime}$ \\
\hline 16 & $\begin{array}{l}\text { Majbal Mzher } \\
\text { Madeuf }\end{array}$ & Al Salman & 80 & $44^{\circ} 58^{\prime}$ & $31^{\circ} 15^{\prime}$ \\
\hline 17 & $\begin{array}{c}\text { Anad Shawael } \\
\text { Darman }\end{array}$ & Al Rameatha & 6 & $45^{\circ} 16^{\prime}$ & $31^{\circ} 42^{\prime}$ \\
\hline 18 & $\begin{array}{c}\text { Fadel Awad } \\
\text { Mohamed }\end{array}$ & Al Salman & 80 & $45^{\circ} 40^{\prime}$ & $30^{\circ} 47^{\prime}$ \\
\hline 19 & $\begin{array}{c}\text { Mohamed } \\
\text { Awad } \\
\text { Mohamed }\end{array}$ & Al Salman & 84 & $45^{\circ} 39^{\prime}$ & $30^{\circ} 47^{\prime}$ \\
\hline 20 & $\begin{array}{c}\text { Abd Alsada } \\
\text { Farhan Samary }\end{array}$ & Al Salman & 85 & $45^{\circ} 39^{\prime}$ & $30^{\circ} 46^{\prime}$ \\
\hline 21 & $\begin{array}{l}\text { Abdul Wahed } \\
\text { Abdul Hur }\end{array}$ & Al Salman & 7 & $44^{\circ} 56^{\prime}$ & $31^{\circ} 16^{\prime}$ \\
\hline 22 & Satar Moueizy & Al Salman & 48 & $45^{\circ} 03$ & $31^{\circ} 18$ \\
\hline 23 & $\begin{array}{c}\text { Ali } \\
\text { FatnanHasaun }\end{array}$ & Al Salman & 71 & $45^{\circ} 02^{\prime}$ & $31^{\circ} 19^{\prime}$ \\
\hline
\end{tabular}


Table 2-Physical and chemical values for water samples in the study area

\begin{tabular}{|c|c|c|c|c|c|c|c|c|c|c|c|}
\hline $\begin{array}{c}\text { Well } \\
\text { No. }\end{array}$ & $\mathrm{pH}$ & $\begin{array}{c}\mathrm{EC} \\
\mu \mathrm{s} / \mathrm{cm}\end{array}$ & $\begin{array}{c}\mathrm{TDS} \\
\mathrm{ppm}\end{array}$ & $\begin{array}{c}\mathrm{K}^{+} \\
\mathrm{ppm}\end{array}$ & $\begin{array}{c}\mathrm{Na}^{+} \\
\mathrm{ppm}\end{array}$ & $\begin{array}{c}\mathrm{Mg}^{+2} \\
\mathrm{ppm}\end{array}$ & $\mathrm{Ca}^{+2} \mathrm{ppm}$ & $\begin{array}{c}\mathrm{CL}^{-} \\
\mathrm{ppm}\end{array}$ & $\begin{array}{c}\mathrm{SO}_{4}{ }^{-2} \\
\mathrm{ppm}\end{array}$ & $\begin{array}{c}\mathrm{HCO}_{3}^{-} \\
\mathrm{ppm}\end{array}$ & $\begin{array}{c}\mathrm{NO}_{3}{ }^{-} \\
\mathrm{ppm}\end{array}$ \\
\hline 1 & 7.42 & 5670 & 3773 & 31 & 528 & 160 & 380 & 750 & 1395 & 335 & 2 \\
\hline 2 & 7.31 & 17550 & 14244 & 75 & 1384 & 373 & 802 & 2202 & 2256 & 1342 & 9 \\
\hline 3 & 7.1 & 6270 & 4500 & 86 & 610 & 145 & 350 & 250 & 670 & 920 & 12 \\
\hline 4 & 7.71 & 4090 & 3800 & 12 & 216 & 141 & 280 & 841 & 790 & 204 & 7.1 \\
\hline 5 & 7.5 & 7090 & 5044 & 12 & 622 & 177 & 362 & 735 & 1461 & 514 & 2 \\
\hline 6 & 7.16 & 4150 & 2968 & 79 & 410 & 127 & 291 & 547 & 1002 & 451 & 5 \\
\hline 7 & 7.16 & 7390 & 5279 & 10 & 800 & 240 & 450 & 1063 & 1739 & 583 & 9 \\
\hline 8 & 7.22 & 7830 & 6437 & 120 & 550 & 164 & 350 & 791 & 1367 & 510 & 2.3 \\
\hline 9 & 7.62 & 8010 & 8700 & 19 & 803 & 249 & 489 & 1060 & 1780 & 549 & 9 \\
\hline 10 & 7.22 & 5930 & 4000 & 9 & 578 & 157 & 365 & 790 & 1300 & 425 & 8 \\
\hline 11 & 7.2 & 5220 & 3863 & 6 & 569 & 142 & 260 & 529 & 1039 & 565 & 4 \\
\hline 12 & 7.15 & 4450 & 3342 & 14 & 680 & 100 & 190 & 568 & 1200 & 410 & 4 \\
\hline 13 & 7.1 & 6330 & 4600 & 86 & 610 & 145 & 380 & 950 & 670 & 920 & 12 \\
\hline 14 & 7.18 & 4230 & 3700 & 85 & 480 & 138 & 300 & 650 & 1123 & 460 & 2 \\
\hline 15 & 7.15 & 4060 & 3650 & 100 & 459 & 137 & 296 & 620 & 439 & 470 & 4 \\
\hline 16 & 7.81 & 6420 & 4760 & 98 & 569 & 160 & 329 & 681 & 1408 & 490 & 2.1 \\
\hline 17 & 7.13 & 1307 & 1290 & 15 & 133 & 87 & 129 & 242 & 551 & 68 & 7 \\
\hline 18 & 7.6 & 5310 & 3890 & 98 & 568 & 160 & 334 & 681 & 1415 & 490 & 3 \\
\hline 19 & 7.15 & 5120 & 3714 & 119 & 540 & 160 & 335 & 722 & 1325 & 510 & 2 \\
\hline 20 & 7.14 & 6730 & 4821 & 99 & 590 & 173 & 340 & 691 & 1540 & 501 & 2.1 \\
\hline 21 & 7.16 & 11640 & 9000 & 78 & 1154 & 337 & 621 & 1598 & 2251 & 1098 & 1.2 \\
\hline 22 & 7.51 & 5970 & 4110 & 95 & 565 & 165 & 336 & 680 & 1412 & 489 & 3.5 \\
\hline 23 & 7.24 & 12520 & 9850 & 79 & 1154 & 337 & 622 & 1597 & 2258 & 1095 & 1.2 \\
\hline Rang. & $7.1-$ & $1307-$ & $1290-$ & $6-$ & $133-$ & $87-$ & $129-802$ & $242-$ & $439-$ & $68-$ & $1.2-$ \\
\hline Mean & 7.81 & 17550 & 14244 & 120 & 1384 & 373 & & 2202 & 2285 & 1342 & 12 \\
\hline & 6664 & 5188 & 61.9 & 633.5 & 181 & 373 & 836 & 1321 & 582 & 4.9 \\
\hline
\end{tabular}

\section{2-Results and Discussion}

\section{2-1: Physical Parameters}

Hydrogen ion concentration (PH): It is the reciprocal of the logarithm (base 10) of the hydrogen ion concentration in moles per liter. $\mathrm{pH}$ is one of the most important operational quality parameters of water [5].Neutral water has a $\mathrm{pH}$ value of 7.0 , alkaline water is more than 7.0 and acidic water has less than 7.0 . Most groundwater has $\mathrm{pH}$ values between 5.0-8.0 but it is usually in the range of 6.5-8.5 [6]. $\mathrm{pH}$ value in the water of study area ranged between 7.1-7.81 with a mean value of 7.3. Most wells were weakly alkaline 7.2-7.6.

Electrical conductivity (EC):It is the ability of $1 \mathrm{~cm}^{3}$ water to conduct an electric current at a standard temperature of $25 \mathrm{C}^{\circ}$ and measured in micro Siemens per centimeter $(\mu . \mathrm{s} \backslash \mathrm{cm})$, depending on the total amount of soluble salts [7]. The variation of conductivity gives important information about the evolution of water quality. EC represents a good evidence to determine the mineralization degree of water [8]. The EC values in groundwater of the study area ranged between 1307-17550 $\mu$.slcm with a mean value of $6664 \mu$.s $\mathrm{lcm}$. Water samples are classified as being of excessively mineralized water (Table-3).

\begin{tabular}{|c|c|c|}
\hline $\mathrm{EC}(\mu \mathrm{S} \backslash \mathrm{cm})$ & Mineralization & The Study area \\
\hline$<100$ & Very weakly mineralized water(granite terrains) & \\
\hline $100-200$ & Weakly mineralized water & \\
\hline $200-400$ & Slightly mineralized water (limestone terrains) & \\
\hline $400-600$ & Moderately mineralized water & \\
\hline
\end{tabular}




\begin{tabular}{|c|c|c|}
\hline $600-1000$ & Highly mineralized water & \\
\hline$>1000$ & Excessively mineralized water & Range(1307-17550) \\
\hline
\end{tabular}

Total Dissolved Solids (TDS): It is a measure of the total amount of minerals dissolved in water and is a very good parameter in the evaluation of water quality [9], also reflecting salinity [10].It is measured by parts per million (ppm) or milligrams per liter $(\mathrm{mg} \backslash \mathrm{L})$ units. The TDS values in the groundwater of the study area ranged between 1290-14244 ppm with a mean of $5188 \mathrm{ppm}$. TDS content of groundwater may increase by movement of water through rocks containing soluble minerals matter, while it is concentrated by evaporation [11].

Total hardness $(\mathrm{TH})$ : Hardness of water is a measure of the capacity for precipitating soup. The primary components of hardness are calcium and magnesium. Hardness is measured by ppm or mg/l units according to the following equation:

$T H=2.497 \mathrm{Ca}^{+2}+4.115 \mathrm{Mg}^{+2}[12]$

where $\mathrm{Ca}^{+2}$ and $\mathrm{Mg}^{+2}$ are the concentrations of ions in ppm. Water is classified into several types according to its total hardness, as in Table 4.

Table 4-Classification of water according to Total hardness

\begin{tabular}{|c|c|c|c|}
\hline \multicolumn{2}{|c|}{ Tood 2007[13] } & \multicolumn{2}{c|}{ Boyd 2000[14] } \\
\hline $\begin{array}{c}\text { Degree of hardness in } \\
\text { ppm }\end{array}$ & Term & Quality of water & $\begin{array}{c}\text { Degree of hardness in } \\
\text { ppm }\end{array}$ \\
\hline $0<\mathrm{TH} \leq 60$ & Soft & Soft & $50 \leq \mathrm{TH}$ \\
\hline $60<\mathrm{TH} \leq 120$ & Moderately hard & Moderately hard & $50<\mathrm{TH} \leq 150$ \\
\hline $120<\mathrm{TH} \leq 180$ & Hard & Hard & $150<\mathrm{TH} \leq 300$ \\
\hline $180<\mathrm{TH}$ & Very hard & Very hard & $300<\mathrm{TH}$ \\
\hline
\end{tabular}

TH values in the study area ranged between 680-2939ppm with a mean value of $1679 \mathrm{ppm}$, which indicates that all samples are of very hard water.

\section{2-2: Chemical Analysis}

Calcium ion $\left(\mathrm{Ca}^{+2}\right)$ : Subsurface water in contact with sedimentary rocks derives most of their calcium from calcite, aragonite, dolomite, anhydrite, and gypsum [15].Some calcium carbonate is desirable for domestic water because it provides liner in the pipes, which protects them against corrosion [16]. Sewage water contains a large quantity of organic materials which, when oxidized, release quantities of $\mathrm{CO}_{2}$, leading to an increase of $\mathrm{Ca}^{+2}$ [17]. Calcium concentration in water samples of the study area ranged between $129-802 \mathrm{ppm}$ with a mean value of $373 \mathrm{ppm}$.

Magnesium $\mathrm{Mg}^{+2:}$ The common sources of magnesium in the hydrosphere are dolomite in sedimentary rocks; olivine, biotite, hornblende, and augite in igneous rocks; and serpentine, talc, diopside, and tremolite in metamorphic rocks. Magnesium is found in lower concentrations than calcium in natural water due to slow dissolution of dolomite together with the greater abundance of calcium in the earth's crust [15]. Magnesium ions concentration in groundwater of the study area ranged between $87-373 \mathrm{ppm}$, with a mean value of $181 \mathrm{ppm}$.

Sodium $\mathrm{Na}^{+}$: Sodium is the most abundant among the alkali elements, and makes up $2.6 \%$ of the earth's crust being the sixth most abundant element over all. The essential source of most sodium in natural water is from the release of dissolvable products during the weathering of plagioclase and feldspars. In areas of evaporatation deposits, the dissolve of halite is also important. Clay minerals may, under proven conditions, release large quantities of commutable sodium [18]. Sodium is a significant factor in assessing water for irrigation and plant watering, where high levels affect soil structure and the plant's ability to take up water [19]. Sodium concentration is important in classifying irrigation water, because sodium reacts with soil to reduce its permeability [13]. Sodium concentration the in study area ranged between 133-1384 ppm with a mean value of $633.5 \mathrm{ppm}$.

Potassium $\mathrm{K}^{+}$: Clay minerals, feldspar, and mica are the main sources of potassium ions, along with evaporates containing highly soluble sylvite in some sedimentary rocks. The concentration of potassium ions is less than the concentration of sodium ions in groundwater, with the reason being the lower solubility of sodium ion [20]. Potassium ion increases in groundwater due to the use of chemical fertilizers [21].Potassium plays an important role in plant growth. In every liter of human blood, there is $180-220 \mathrm{mg} / \mathrm{L}$ of potassium, and the lack of this amount, as well as increasing it, causes disturbance 
in the body [5]. Potassium concentration in water samples of the study area ranged between 6-120 ppm with a mean value of $61.7 \mathrm{ppm}$. High concentration of potassium in some samples of the study areais due to the effect of agricultural fertilizers.

Chloride $\mathrm{CL}^{-}$: Chloride is a minor constituent of the earth's crust, but a major dissolved constituent of most natural water. It represents an important element in the hydrologic cycle, where its content in rain water is usually less than $10 \mathrm{ppm}$, whereas in groundwater it varies from few ppm in the snow-fed wells to high content in desert brines. Chloride ion is available in evaporated rocks and in rock minerals such as apatite and soda [22]. In addition, the treatment of water with chloride can lead to increased concentrations in the groundwater [5]. Chloride concentration in the water samples of the study area ranged between 242-2202 ppm with a mean value of $836 \mathrm{ppm}$. High chloride concentration in groundwater of the study area may be an indicator to pollution by sewage and agriculture fertilizers. * Sulfate $\left(\mathrm{SO}_{4}{ }^{-2}\right)$ : Sedimentary rocks such as gypsum and anhydrite represent an important source of sulfate [13], while other sources are agricultural and industrial activities [23]. Sulfate concentration in the water samples of the study area ranged between $439-2285 \mathrm{ppm}$ with a mean value of $1321 \mathrm{ppm}$. All water wells of the study area do not meet with the standard concentration of IQS 2009[24] (400 ppm) and WHO 2007[25](250 ppm).

Bicarbonate $\left(\mathrm{HCO}_{3}^{-}\right)$: The primary source of bicarbonate ion in groundwater is the melting of calcareous rocks in water, which contain the dissolved carbon dioxide of dissolved carbon, as well as the presence of hydrogen ion resulting from the dissolution of carbonic acid. Decay of organic matter may also release carbon dioxide for dissolution[26]. The concentrations of bicarbonate in the study area ranged between 68-1342ppm with a mean of $582 \mathrm{ppm}$.

Nitrate $\left(\mathrm{NO}_{3}{ }^{-}\right)$: Organic matters and fertilizers represent the most common sources of nitrates in natural water; they originate from industrial and agricultural activities [27], [28]. Nitrate has a direct effect on plant growth and may cause a hazard for drinking water sources if the levels reach to $10 \mathrm{ppm}$ or higher [29]. Nitrate concentration in the study area ranged between 1.2-12ppm with a mean value of $4.9 \mathrm{ppm}$. Nitrate concentrations in the study area are lower than the standards values of IQS 2009[24] and WHO 2007[25] (50 ppm for both guidelines).

2-3 Water types and hydro chemical formula: Types of water are connected to the chemical and physical properties, which change relatively with respect to time and space. These changes are slow in groundwater compared with surface water [30]. Water type is very important to determine its suitability for the different uses (human, agricultural, and industrial purposes). Many classifications depend on the concentrations of main cations and anions by unit equivalent weight of ion $(\mathrm{epm})($ Table-5) or milli equivalent per liter (meq / 1).

Table 5-Chemical analysis of groundwater samples in epm units.

\begin{tabular}{|c|c|c|c|c|c|c|c|c|c|c|c|}
\hline W.No. & $\mathrm{K}^{+}$ & $\mathrm{Na}^{+}$ & $\mathrm{Mg}^{+2}$ & $\mathrm{Ca}^{+2}$ & $\mathrm{CL}^{-}$ & $\mathrm{SO}_{4}^{-2}$ & $\mathrm{HCO}_{3}^{-}$ & $\mathrm{NO}_{3}^{-}$ & $\mathrm{RSC}$ & $\mathrm{Na} \%$ & $\mathrm{SAR}$ \\
\hline 1 & 0.79 & 22.9 & 13.3 & 19.0 & 21.1 & 29.6 & 5.4 & 0.02 & -26.8 & 42.3 & 5.7 \\
\hline 2 & 1.92 & 60.1 & 31.08 & 40.1 & 62.0 & 47 & 5.6 & 0.14 & -65.5 & 46.5 & 10.8 \\
\hline 3 & 2.2 & 26.5 & 12.08 & 17.5 & 7.04 & 13.9 & 15.08 & 0.19 & -14.5 & 49.6 & 6.8 \\
\hline 4 & 0.3 & 9.3 & 11.7 & 14 & 23.6 & 16.4 & 3.34 & 0.11 & -22.4 & 27.3 & 2.6 \\
\hline 5 & 0.3 & 27 & 14.7 & 18.1 & 20.7 & 30.4 & 8.4 & 0.03 & -24.4 & 45.4 & 6.6 \\
\hline 6 & 2.02 & 17.8 & 10.5 & 14.5 & 15.4 & 20.8 & 7.39 & 0.08 & -17.7 & 44.1 & 5.03 \\
\hline 7 & 0.25 & 34.7 & 20 & 22.5 & 29.9 & 36.2 & 8.81 & 0.14 & -33.2 & 45.1 & 7.5 \\
\hline 8 & 3.07 & 23.9 & 13.6 & 17.5 & 22.2 & 28.4 & 8.3 & 0.03 & -22.8 & 46.4 & 6.05 \\
\hline 9 & 0.48 & 34.9 & 20.7 & 24.4 & 29.8 & 37 & 9 & 0.14 & -36.1 & 43.9 & 7.35 \\
\hline 10 & 0.23 & 25.1 & 13.08 & 18.2 & 22.2 & 27 & 6.96 & 0.12 & -24.3 & 44.7 & 6.35 \\
\hline 11 & 0.15 & 24.7 & 11.83 & 13 & 14.9 & 21.6 & 9.26 & 0.06 & -15.5 & 50 & 7.01 \\
\hline 12 & 0.35 & 29.5 & 8.33 & 9.5 & 16 & 25 & 6.72 & 0.06 & -11.1 & 62.6 & 9.9 \\
\hline 13 & 2.2 & 26.5 & 12.08 & 19 & 26.7 & 13.9 & 15 & 0.19 & -16 & 48 & 6.72 \\
\hline 14 & 2.17 & 20.8 & 11.5 & 15 & 18.3 & 23.3 & 7.5 & 0.03 & -18.9 & 23 & 5.73 \\
\hline 15 & 2.5 & 19.9 & 11.41 & 14.8 & 17.4 & 9.1 & 7.7 & 0.06 & -18.5 & 46.2 & 5.51 \\
\hline 16 & 2.51 & 24.7 & 13.33 & 16.4 & 19.1 & 29.3 & 8.03 & 0.03 & -21.7 & 47.7 & 6.41 \\
\hline 17 & 0.38 & 5.78 & 7.25 & 6.45 & 6.81 & 11.4 & 1.11 & 0.11 & -12.4 & 31 & 2.21 \\
\hline 18 & 2.51 & 24.6 & 13.33 & 16.7 & 19.1 & 29.4 & 8.03 & 0.04 & -22 & 47.5 & 6.37 \\
\hline
\end{tabular}




\begin{tabular}{|c|c|c|c|c|c|c|c|c|c|c|c|}
\hline 19 & 3.05 & 23.4 & 13.33 & 16.7 & 20.3 & 27.6 & 8.36 & 0.03 & -21.7 & 46.8 & 6.05 \\
\hline 20 & 2.53 & 25.6 & 14.41 & 17 & 19.4 & 32 & 8.21 & 0.03 & -23.2 & 47.2 & 6.47 \\
\hline 21 & 2 & 50.1 & 28.08 & 31 & 45 & 46.8 & 18 & 0.01 & -41.1 & 46.8 & 9.22 \\
\hline 22 & 2.43 & 24.56 & 13.75 & 16.8 & 19.1 & 29.4 & 8.01 & 0.05 & -22.5 & 46.9 & 6.28 \\
\hline 23 & 2.02 & 50.17 & 28 & 31.1 & 44.9 & 47 & 17.9 & 0.01 & -41.2 & 46.8 & 9.22 \\
\hline \multirow{2}{*}{ Rang. } & $0.15-$ & $5.78-$ & $7.25-$ & $6.45-$ & $6.81-$ & $11.4-$ & $1.11-$ & $0.01-$ & -65.5 & $23-$ & $2.2-$ \\
& 3.07 & 60.1 & 31.08 & 40.1 & 62 & 47 & 17.9 & 0.19 & to -1 & 62.6 & 10.8 \\
\hline mean & 1.58 & 27.5 & 15.1 & 18.6 & 23.5 & 27.5 & 8.78 & 1.71 & -24.2 & 44.6 & 6.6 \\
\hline
\end{tabular}

The hydrochemical formula is defined as an equivalent weight ratio for all ions having a ratio of higher than $15 \%$ in groundwater, which are arranged regularly according to the concentration of each ion, in addition to TDS and $\mathrm{pH}$ values. The result of this formula determines the water type. The formula (also called Kurlolov formula) was taken from Ivanov 1968[31] is:

$T D S(m g \backslash l) \frac{\text { Anions epm } \% \text { in decreasing order }}{\text { Cations epm\% in decreasing order }} p H$

Table- 6 shows the type of groundwater in the studied area, as resulted from the use of the hydrochemical formula. It is an important measure in geochemical reactions through the flow of groundwater, where the increase in flow length will change the water quality from bicarbonate to sulfate and chloride. This could be an indicator to the length of groundwater flow [32]. We note from the results that most wells are of a sulfate water type.

Table 6-Hydrochemical formula results of groundwater samples

\begin{tabular}{|c|c|c|}
\hline $\begin{array}{l}\text { Well } \\
\text { No. }\end{array}$ & Hydro chemical formula & Water type \\
\hline \multirow{2}{*}{1} & $\mathrm{SO}_{4}^{-2}(52.17) \mathrm{CL}^{-}(37.9) \mathrm{HCO}_{3}^{-}(9.8) \mathrm{NO}_{3}^{-}(0.05)$ & \multirow{2}{*}{$\mathrm{Na}^{+}$- Sulfate } \\
\hline & $3 7 \longdiv { \mathrm { Na } ^ { + } ( 4 0 . 9 5 ) \mathrm { Ca } ^ { + 2 } ( 3 3 . 8 ) \mathrm { Mg } ^ { + 2 } ( 2 3 . 7 ) \mathrm { K } ^ { + } ( 1 . 3 ) }$ & \\
\hline \multirow{2}{*}{2} & $14244 \frac{\mathrm{CL}-(54.04) \mathrm{SO} 4-2(40.95) \mathrm{HCO}-(4.8) \mathrm{NO} 3-(0.12)}{731}$ & \multirow{2}{*}{$\mathrm{Na}^{+}$- Chloride } \\
\hline & $14244 \overline{\mathrm{CL}-(54.04) \mathrm{SO} 4-2(40.95) \mathrm{HCO} 3-(4.8) \mathrm{NO}-(0.12)} 7.31$ & \\
\hline \multirow{2}{*}{3} & $\mathrm{HCO} 3-(41.58) \mathrm{SO} 4-2(38.46) \mathrm{CL}-(19.41) \mathrm{NO} 3-(0.53)$ & \multirow{2}{*}{$\begin{array}{c}\mathrm{Na}^{+}- \\
\text {Bicarbonate }\end{array}$} \\
\hline & $\mathrm{Na}+(45.4) \mathrm{Ca}+2(30.01) \mathrm{Mg}+2(20.7) \mathrm{K}+(3.7)$ & \\
\hline \multirow{2}{*}{4} & CL $-(54.3) \mathrm{SO} 4-2(37.3) \mathrm{HCO} 3-(7.6) \mathrm{NO} 3-(0.26)$ & \multirow{2}{*}{$\mathrm{Ca}^{+2}$ - Chloride } \\
\hline & $\mathrm{Ca}+2(39.5) \mathrm{Mg}+2(33.1) \mathrm{Na}+(26.4) \mathrm{K}+(0.86)$ & \\
\hline \multirow{2}{*}{5} & SO4 - 2(51.07) CL $-(34.2) \mathrm{HCO} 3-(14.13) \mathrm{NO} 3-(0.05)$ & \multirow{2}{*}{$\mathrm{Na}^{+}$- Sulfate } \\
\hline & $\mathrm{Na}+(44.9) \mathrm{Ca}+2(30.07) \mathrm{Mg}+2(24.5) \mathrm{K}+(0.49)$ & \\
\hline \multirow[b]{2}{*}{6} & $\mathrm{SO} 4-2(47.7) \mathrm{CL}-(35.2) \mathrm{HCO} 3-(16.8) \mathrm{NO}-(0.18)$ & \multirow[b]{2}{*}{$\mathrm{Na}^{+}$- Sulfate } \\
\hline & $\mathrm{Na}+(39.6) \mathrm{Ca}+2(32.3) \mathrm{Mg}+2(23.5) \mathrm{K}+(4.49)$ & \\
\hline \multirow{2}{*}{7} & SO4 - 2(48.2) CL - (39.8) HCO3 - (11.7) NO3 - (0.19) & \multirow{2}{*}{$\mathrm{Na}^{+}$- Sulfate } \\
\hline & $\mathrm{Na}+(44.8) \mathrm{Ca}+2(29.02) \mathrm{Mg}+2925.7) \mathrm{K}+(0.3)$ & \\
\hline \multirow{2}{*}{8} & $\mathrm{SO} 4-2(48.1) \mathrm{CL}-(37.6) \mathrm{HCO} 3-(14.1) \mathrm{NO} 3-(0.05)$ & \multirow{2}{*}{$\mathrm{Na}^{+}$- Sulfate } \\
\hline & $\mathrm{Na}+(41.1) \mathrm{Ca}+2(30.09) \mathrm{Mg}+2(23.4) \mathrm{K}+(5.2)$ & \\
\hline 9 & $8700 \frac{\mathrm{SO} 4-2(48.7) \mathrm{CL}-(39.2) \mathrm{HCO} 3-(11.8) \mathrm{NO} 3-(0.19)}{\mathrm{Na}+(43.3) \mathrm{Ca}+2(30.3) \mathrm{Mg}+2(25.7) \mathrm{K}+(0.59)} 7.62$ & $\mathrm{Na}^{+}$- Sulfate \\
\hline \multirow{2}{*}{10} & $\mathrm{SO} 4-2(47.9) \mathrm{CL}-(39.4) \mathrm{HCO}-(12.33) \mathrm{NO}-(0.2)$ & \multirow{2}{*}{$\mathrm{Na}^{+}$- Sulfate } \\
\hline & $\mathrm{Na}+(44.3) \mathrm{Ca}+2(32.1) \mathrm{Mg}+2(23.07) \mathrm{K}+(0.4)$ & \\
\hline \multirow{2}{*}{11} & 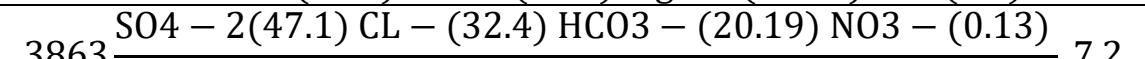 & \multirow{2}{*}{$\mathrm{Na}^{+}$- Sulfate } \\
\hline & $\mathrm{Na}+(49.7) \mathrm{Ca}+2(26.1) \mathrm{Mg}+2(23.12) \mathrm{K}+(0.3)$ & \\
\hline \multirow{2}{*}{12} & SO4 - $2(52.3) \mathrm{CL}-(33.4) \mathrm{HCO} 3-(14.06) \mathrm{NO} 3-(0.12)$ & \multirow{2}{*}{$\mathrm{Na}^{+}$- Sulfate } \\
\hline & $\mathrm{Na}+(61.9) \mathrm{Ca}+2(19.8) \mathrm{Mg}+2(17.4) \mathrm{K}+(0.7)$ & \\
\hline \multirow{2}{*}{13} & $\mathrm{CL}-(47.8) \mathrm{HCO} 3-(26.9) \mathrm{SO} 4-2(24.9) \mathrm{NO} 3-(0.34)$ & \multirow{2}{*}{$\mathrm{Na}^{+}$- Chloride } \\
\hline & $\mathrm{Na}+(44.3) \mathrm{Ca}+2(31.7) \mathrm{Mg}+2(20.2) \mathrm{K}+(3.6)$ & \\
\hline
\end{tabular}




\begin{tabular}{|c|c|c|}
\hline 14 & $3700 \frac{\mathrm{SO} 4-2(47.4) \mathrm{CL}-(37.1) \mathrm{HCO}-(15.3) \mathrm{NO}-(0.06)}{\mathrm{Na}+(42.1) \mathrm{Ca}+2(30.2) \mathrm{Mg}+2(23.2) \mathrm{K}+(4.3)} 7.18$ & $\mathrm{Na}^{+}$- Sulfate \\
\hline 15 & $3650 \frac{\mathrm{CL}-(50.8) \mathrm{SO} 4-2(26.6) \mathrm{HCO}-(22.4) \mathrm{NO}-(0.17)}{\mathrm{Na}+(40.9) \mathrm{Ca}+2(30.3) \mathrm{Mg}+2(23.4) \mathrm{K}+(5.2)} 7.15$ & $\mathrm{Na}^{+}$- Chloride \\
\hline 16 & $4760 \frac{\mathrm{SO} 4-2(51.8) \mathrm{CL}-(33.9) \mathrm{HCO}-(14.19) \mathrm{NO} 3-(0.05)}{\mathrm{Na}+(43.3) \mathrm{Ca}+2(28.8) \mathrm{Mg}+2(23.3) \mathrm{K}+(4.4)} 7.81$ & $\mathrm{Na}^{+}$- Sulfate \\
\hline 17 & $1290 \frac{\mathrm{SO} 4-2(58.8) \mathrm{CL}-(34.9) \mathrm{HCO} 3-(5.9) \mathrm{NO}-(0.5)}{\mathrm{Mg}+2(36.5) \mathrm{Ca}+2(32.4) \mathrm{Na}+(29.1) \mathrm{K}+(1.9)} 7.13$ & $\mathrm{Mg}^{+2}-$ Sulfate \\
\hline 18 & $3890 \frac{\mathrm{SO} 4-2(51.9) \mathrm{CL}-(33.8) \mathrm{HCO}-(14.15) \mathrm{NO}-(0.08)}{\mathrm{Na}+(43.1) \mathrm{Ca}+2(29.1) \mathrm{Mg}+2(23.2) \mathrm{K}+(4.3)} 7.6$ & $\mathrm{Na}^{+}$- Sulfate \\
\hline 19 & $3714 \frac{\mathrm{SO} 4-2(49.0) \mathrm{CL}-(36.09) \mathrm{HCO} 3-(14.8) \mathrm{NO} 3-(0.05)}{\mathrm{Na}+(41.4) \mathrm{Ca}+2(29.5) \mathrm{Mg}+2(23.5) \mathrm{K}+(5.3)} 7.15$ & $\mathrm{Na}^{+}$- Sulfate \\
\hline 20 & $4821 \frac{\mathrm{SO} 4-2(53.6) \mathrm{CL}-(32.5) \mathrm{HCO}-(13.7) \mathrm{NO}-(0.05)}{\mathrm{Na}+(43.04) \mathrm{Ca}+2(28.5) \mathrm{Mg}+2(24.1) \mathrm{K}+(} 7.14$ & $\mathrm{Na}^{+}$- Sulfate \\
\hline 21 & $9000 \frac{\mathrm{SO} 4-2(42.6) \mathrm{CL}-(40.9) \mathrm{HCO}-(16.3) \mathrm{NO3}-(0.01)}{\mathrm{Na}+(45.07) \mathrm{Ca}+2(27.8) \mathrm{Mg}+2(25.2) \mathrm{K}+(1.7)} 7.16$ & $\mathrm{Na}^{+}$- Sulfate \\
\hline 22 & $4110 \frac{\mathrm{SO} 4-2(51.9) \mathrm{CL}-(33.8) \mathrm{HCO}-(14.14) \mathrm{NO} 3-(0.09)}{\mathrm{Na}+(42.6) \mathrm{Ca}+2(29.10 \mathrm{Mg}+2(23.8) \mathrm{K}+(4.20)}$ & $\mathrm{Na}^{+}$- Sulfate \\
\hline 23 & $9850 \frac{\mathrm{SO} 4-2(42.7) \mathrm{CL}-(40.8) \mathrm{HCO} 3-(16.3) \mathrm{NO}-(0.01)}{\mathrm{Na}+(45.04) \mathrm{Ca}+2(27.9) \mathrm{Mg}+2(25.2) \mathrm{K}+(1.8)} 7.24$ & $\mathrm{Na}^{+}$- Sulfate \\
\hline
\end{tabular}

2-4 Usability of groundwater in the study area

Groundwater is used for several purposes depending on the type of water and its content of anions and cations that change it from one type to another. Therefore, it is necessary to evaluate the water according to the local and world standard specifications to determine the suitability of water to the different uses like domestic, agricultural and industrial ones [12].

2-4-1 Usage of water for drinking

Groundwater forms an important source of water for drinking and other domestic purposes, especially in some arid and semi-arid regions where surface water is scarce. Iraqi drinking standards (IQS,2009)[24] and those of the world health organization (WHO,2007)[25]are used to determine the suitability of groundwater in the studied area for human drinking purposes, depending on the ions concentrations in water, TDS and other components (Table-7 ). Overall, it seems that the current groundwater for all studied wells is not suitable for human drinking, because levels of most of the elements not within the recommended guideline levels.

Table 7-Comparison of results of parameters of water samples with the standards of drinking water IQS, 2009)[24] and WHO, 2007[25]

\begin{tabular}{|c|c|c|c|c|}
\hline Parameters & $\begin{array}{l}\text { IQS } \\
2009\end{array}$ & $\begin{array}{l}\text { WHO } \\
2007\end{array}$ & $\begin{array}{l}\text { studied wells } \\
\text { (range) }\end{array}$ & Suitability of the samples in the study area \\
\hline $\mathrm{pH}$ & $6.5-8.5$ & $6.5-8.5$ & $7.1-7.8$ & All samples are suitable \\
\hline $\mathrm{EC}(\mu \mathrm{S} / \mathrm{cm})$ & 1500 & 1530 & $1307-17550$ & All samples are not suitable except 17 \\
\hline TDS(ppm) & 1000 & 1000 & $1290-14244$ & All samples are not suitable \\
\hline $\mathrm{Ca}^{+2}(\mathrm{ppm})$ & 150 & 75 & $129-802$ & All samples are not suitable except 17 \\
\hline $\mathrm{Mg}^{+2}(\mathrm{ppm})$ & 100 & 125 & $87-373$ & $\begin{array}{l}\text { All samples are not suitable except } 12 \text { and } \\
\qquad 17\end{array}$ \\
\hline $\mathrm{Na}^{+}(\mathrm{ppm})$ & 200 & 200 & $133-1384$ & Not Suitable except sample 17 \\
\hline $\mathrm{K}^{+}(\mathrm{ppm})$ & - & 12 & $6-120$ & Only samples $(4,5,7,10,11)$ are suitable \\
\hline $\mathrm{CL}^{-}(\mathrm{ppm})$ & 350 & 250 & $242-2202$ & All samples are not suitable except 3 and 17 \\
\hline $\mathrm{SO}_{4}^{-2}(\mathrm{ppm})$ & 400 & 250 & $439-2285$ & All sample are not Suitable \\
\hline $\mathrm{NO}_{3}^{-}(\mathrm{ppm})$ & 50 & 50 & $1.2-12$ & All samples are suitable \\
\hline
\end{tabular}

2-4-2 Water suitability for irrigation and agricultural purposes

These uses depend upon several factors such as sodium adsorption ratio (SAR), residual sodium carbonate (RSC), EC, TDS, and sodium concentration percentage (Na \%). 
One of the important classifications of the irrigation water depends on the salinity (EC\&TDS)[33] as shown in (Table-8).

Table 8-classification of water for irrigation and agriculture purposes

\begin{tabular}{|c|c|c|c|c|}
\hline $\begin{array}{l}\text { Water } \\
\text { class }\end{array}$ & $\begin{array}{c}\mathrm{EC} \\
\mu \mathrm{S} / \mathrm{cm}\end{array}$ & TDS ppm & Type of water & $\begin{array}{c}\text { Samples of the Study } \\
\text { area }\end{array}$ \\
\hline $\begin{array}{l}\text { Non- } \\
\text { Saline }\end{array}$ & $<700$ & $<500$ & Drinking and irrigation water & \\
\hline $\begin{array}{l}\text { Slightly } \\
\text { Saline }\end{array}$ & $700-2000$ & $500-1500$ & Irrigation Water & 17 \\
\hline $\begin{array}{l}\text { Moderate } \\
\text { Saline }\end{array}$ & $\begin{array}{l}2000- \\
10000\end{array}$ & $1500-7000$ & $\begin{array}{l}\text { Primary drainage water and } \\
\text { groundwater }\end{array}$ & $\begin{array}{c}1,3,4,5,6,7,8,9,10,11,12,13 \\
14,15,16,18,19,20,22 \\
\end{array}$ \\
\hline $\begin{array}{l}\text { Highly } \\
\text { Saline }\end{array}$ & $\begin{array}{l}10000- \\
25000\end{array}$ & $7000-15000$ & $\begin{array}{l}\text { Secondary drainage water } \\
\text { and groundwater }\end{array}$ & $2,21,23$ \\
\hline $\begin{array}{c}\text { Very } \\
\text { highly } \\
\text { Saline }\end{array}$ & $\begin{array}{l}25000- \\
45000\end{array}$ & $\begin{array}{l}15000- \\
35000\end{array}$ & Very saline groundwater & \\
\hline brine & $>45000$ & $>35000$ & Sea water & \\
\hline
\end{tabular}

Comparing with this standard, the groundwater samples of the study area are moderate saline .

Residual sodium carbonate (RSC): A high concentration of bicarbonate in irrigation water may lead to the precipitation of calcium and magnesium in the soil and thus to a relative increase of sodium concentration. Therefore, the sodium hazard will increase [34]. The bicarbonate hazard is expressed by RSC which was introduced by Eaton, 1950[35], as follows:

$\mathrm{RSC}=\left(\mathrm{CO}_{3}^{-2}+\mathrm{HCO}_{3}^{-}\right)-\left(\mathrm{Ca}^{+2}+\mathrm{Mg}^{+2}\right)$.

Where all ions are measured by the equivalent weight (epm)(Table-5).RSC values in the study area ranged between -65.5 to -11 epm with a mean of -24.2. According to the classification of Eaton, 1950,[35] (Table 9), all the samples of groundwater in the study area are safe for irrigation.

Table 9-Classification of irrigation water based on RSC values (Eaton, 1950)[35]

\begin{tabular}{|c|c|c|}
\hline RSC (epm) & Water type & Area study \\
\hline$<1.25$ & Safe & All samples( negative values) \\
\hline $1.25-2.5$ & Marginal & \\
\hline$>2.5$ & Unsuitable & \\
\hline
\end{tabular}

Soluble sodium percentage $(\mathrm{Na} \%)$ and EC: Sodium content is commonly expressed in terms of sodium percentage. Increasing sodium ion ratio in irrigation water will affect soil efficiency, where it leads to a decrease in its porosity and permeability, and thus will affect the plant growth or stunted growth. $\mathrm{Na} \%$ value is calculated according to the following equation:

$N a \%=(r N a+r K / r C a+r M g+r N a+r K) \times 100 \quad[12]$

Where all ionic concentrations $(\mathrm{rNa}, \mathrm{rK}, \mathrm{rCa}, \mathrm{rMg}$ ) are expressed in epm $\mathrm{Na} \%$ values in the study area ranged between 23-62.5 with a mean of 44.6. The classification of Tood ,1980 [12], for irrigation water based on $\mathrm{Na} \%$ and EC values (Table-7) was adopted in this study, while the results of this study are explained in Table- 10 .

Table 10-The results according to the classification of Todd (1980)[12] for irrigation water based on $\mathrm{Na} \%$ and EC.

\begin{tabular}{|c|c|c|c|c|}
\hline Water class & $\mathrm{Na} \%$ & Study area & $\mathrm{EC} \mu \mathrm{S} / \mathrm{Cm}$ & Study area \\
\hline Excellent & $<20$ & & $<250$ & \\
\hline Good & $20-40$ & Well no. 4,14,17 & $250-750$ & \\
\hline Permissible & $40-60$ & Most samples & $750-2000$ & Only sample no. 17 \\
\hline Doubtful & $60-80$ & Well no.12 & $2000-3000$ & \\
\hline Unsuitable & $>80$ & & $>3000$ & All samples except 17 \\
\hline
\end{tabular}


Sodium adsorption ratio (SAR): The two most common water quality factors that influence the normal rate of infiltration are the salinity of water and the relative concentrations of sodium versus magnesium and calcium ions in the water, known as the SAR. It is an important parameter for determining the suitability of water for agriculture, because it is a measure of alkali /sodium hazard [36]. Karanth, 2008[37], defines SAR of water as:

$\mathrm{SAR}=\frac{\mathrm{Na}^{+}}{\left.\left\{\sqrt{\left(\mathrm{Ca}^{+2}\right.}+\mathrm{Mg}^{+2}\right) / 2\right\}}$

where $\mathrm{Na}^{+}, \mathrm{Ca}^{+2}$ and $\mathrm{Mg}^{+2}$ are concentrations of ions in epm units. High values of SAR imply a hazard of sodium replacing absorbed calcium and magnesium, a situation that is ultimately damaging to soil structure[22]. There are four classes of water for agriculture depending on SAR value according to Subramain ,2005[36]. All samples in the study area had a SAR value that is lower than 10 except sample No.2 (10.8), whereas the range was between 2.2-10.8 epm and the mean was 6.6epm. These results indicate an excellent water class(S1) for agriculture(Table-11).

Table 11- Alkalinity hazard classes of water (Subramain, 2005)[36]

\begin{tabular}{|c|c|c|c|}
\hline SAR (epm) & Alkalinity hazard & Water class & Representing samples \\
\hline$<10$ & S1 & Excellent & All samples (except no.2) \\
\hline $10-18$ & S2 & Good & Sample no.2 \\
\hline $18-26$ & S3 & Doubtful & \\
\hline$>26$ & S4 & Unsuitable & \\
\hline
\end{tabular}

2-4-3: Groundwater uses for livestock: Samples of the study area were evaluated for livestock and poultry used by the classification proposed by Altoviski (1962)[38] (Table-12).

Table 12-Specifications of water samples for livestock consumption according to Altoviski (1962)[38].

\begin{tabular}{|c|c|c|c|c|c|c|}
\hline $\begin{array}{c}\text { Parameters } \\
(\mathrm{ppm})\end{array}$ & $\begin{array}{c}\text { Very } \\
\text { good } \\
\text { water }\end{array}$ & $\begin{array}{c}\text { Good } \\
\text { water }\end{array}$ & $\begin{array}{c}\text { Acceptable } \\
\text { water for use }\end{array}$ & $\begin{array}{c}\text { Can be } \\
\text { used }\end{array}$ & High limits & $\begin{array}{c}\text { Study area } \\
\text { (range) }\end{array}$ \\
\hline $\mathrm{Na}^{+}$ & 800 & 1500 & 2000 & 2500 & 4000 & $133-1384$ \\
\hline $\mathrm{Ca}^{+2}$ & 350 & 700 & 800 & 900 & 1000 & $129-802$ \\
\hline $\mathrm{Mg}^{+2}$ & 150 & 350 & 500 & 600 & 700 & $87-373$ \\
\hline $\mathrm{CL}^{-}$ & 900 & 2000 & 3000 & 4000 & 6000 & $242-2202$ \\
\hline $\mathrm{SO}_{4}^{-2}$ & 1000 & 2500 & 3000 & 4000 & 6000 & $439-2285$ \\
\hline $\mathrm{TDS}$ & 3000 & 5000 & 7000 & 10000 & 15000 & $1290-14244$ \\
\hline $\mathrm{TH}$ & 1500 & 3200 & 4000 & 4700 & 54000 & $680-2939$ \\
\hline
\end{tabular}

Over all, it seems that the current groundwater for all studied wells is suitable to use for livestock purposes , but the degree of suitability is different from well to another, ranging between very good to acceptable for use according to Altoviski 1962[38] classification.

2-4-4 Water suitability for industrial purposes: Water samples for the study area were determined for industrial purposes by using Hem(1985)[22] classification (Table-13).

Table 13-Water quality standards for industrial purposes[22]

\begin{tabular}{|c|c|c|c|c|c|c|c|c|c|}
\hline Industry type & $\begin{array}{c}\mathrm{Ca}^{+2} \\
\mathrm{ppm}\end{array}$ & $\begin{array}{c}\mathrm{Mg}^{+2} \\
\mathrm{ppm}\end{array}$ & $\begin{array}{c}\mathrm{CL}^{-} \\
\mathrm{ppm}\end{array}$ & $\begin{array}{c}\mathrm{HCO}_{3}^{-} \\
\mathrm{ppm}\end{array}$ & $\begin{array}{c}\mathrm{SO}_{4}^{-2} \\
\mathrm{ppm}\end{array}$ & $\begin{array}{c}\mathrm{NO}_{3-}^{-} \\
\mathrm{ppm}\end{array}$ & $\begin{array}{c}\mathrm{TH} \\
\mathrm{ppm}\end{array}$ & $\begin{array}{c}\mathrm{TDS} \\
\mathrm{ppm}\end{array}$ & $\mathrm{pH}$ \\
\hline Cement & - & - & 250 & - & 250 & - & - & 600 & $6.5-8.5$ \\
\hline Wood & 100 & 50 & 500 & 250 & 100 & 5 & 900 & 1000 & $6.5-8$ \\
\hline Leathers & - & - & 250 & - & 250 & - & - & - & $6-8$ \\
\hline $\begin{array}{c}\text { Soft drinks } \\
\text { bottling }\end{array}$ & 100 & - & 500 & - & 500 & - & - & - & - \\
\hline Fruit icing & - & - & 250 & - & 250 & 10 & 250 & 500 & $6.5-8.5$ \\
\hline $\begin{array}{c}\text { Water of study } \\
\text { area(mean) }\end{array}$ & 373 & 181 & 836 & 582 & 1321 & 4.9 & 1679 & 5188 & 7.3 \\
\hline
\end{tabular}


According to this classification, groundwater in the study area is not suitable for most types of industries.

2-4-5 Suitability of water resources for building purposes:

Altoviski (1962)[38] classification for building purposes depends on the levels of most of the major cations and anions and was used to evaluate the suitability of water samples in the studied area for building purposes (Table-14).

Table 14-Evaluation of water for building purposes [38].

\begin{tabular}{|c|c|c|c|}
\hline \multirow{2}{*}{ Ions (ppm) } & \multirow{2}{*}{ Permissible limit } & range & Water studied area \\
\hline $\mathrm{Na}^{+}$ & 1160 & $133-1384$ & 633.5 \\
\hline $\mathrm{Ca}^{+2}$ & 437 & $129-802$ & 373 \\
\hline $\mathrm{Mg}^{+2}$ & 271 & $87-373$ & 181 \\
\hline $\mathrm{CL}^{-}$ & 2187 & $242-2202$ & 836 \\
\hline $\mathrm{SO}_{4}^{-2}$ & 1460 & $439-2285$ & 1321 \\
\hline $\mathrm{HCO}_{3}^{-}$ & 350 & $68-1342$ & 582 \\
\hline
\end{tabular}

It is clear that groundwater in study area are suitable for building purposes.

\section{3-Conclusions}

Depending on $\mathrm{pH}$ value of water, in study area, the water is suitable for different uses.

According to the high value of electrical conductivity (EC), the groundwater of study area is classified as excessively mineralized according to Detay, 1997[8].The high value of total dissolved solids (TDS) in water is attributed to the long flow path of groundwater. Depending on total hardness (TH) parameter, all samples showed very hard water according to Tood, 2007[13] and Boyd, 2000[14] classification. This may mostly be a result of the presence of Rus Formation.The predominant cations in water of the study area are sodium and calcium, whereas sulfate and chloride are the most common anions, thus the water type is $\mathrm{Na}^{+}$-Sulfate for most samples in the study area.

The groundwater in the studied wells is not suitable for human drinking. Depending on TDS and EC values, the water samples are from moderate saline class. Water type is safe for irrigation according to Eaton 1950[35],depending on RSC. An excellent water class was found depending on $\mathrm{Na} \%$ and EC, according to Tood, 1980[12] classification for irrigation water. Excellent water class (S1) for agriculture was found depending on SAR, according to Subramain, 2005[36]classification. Groundwater for all studied wells is suitable to use for livestock purposes according to Altoviski, 1962[38] classification. It is clear that groundwater in the study area is suitable for building purposes according to Altoviski, 1962[38] classification.

\section{4-References}

1. Sissakian, V.K. 2000. Geological Map of Iraq. Scale 1: 1000 000, 3rd edit. GEOSURV, Baghdad, Iraq.

2. Owen,R.M. and Naser,S.N.,1958. The stratigraphic of Kuwait- Basra area. In Week L.G. (editor):Habitat of oil , asymposium.Am.Assos.petr.Geol.,Tulsa.

3. Jassim,S.Z. and Goff,J.C.(editor),2006.Geology of Iraq. Puplished by Dolin, Prague and Moravian Museum, Berno.p.341 .

4. Bellen,R.C.,Van Dunnington, H.V.,Wetzel,R.and Morton,D. 1959.Lexique stratigraphic international. Asia ,Fasc.10a, Iraq ,paris,333pp.

5. World Health Organization (WHO), 2006: Guidelines for drinking water quality. Third ed., Vol.1, Recommendations, Geneva, pp.515.

6. World Health Organization (WHO), 2011: Guidelines for drinking water quality $.4^{\text {th }}$ ed. WHO press, Geneva, pp564.ISBN:9789241548151.

7. Tood, D.K. 2005. Groundwater hydrology $.2^{\text {nd }}$ Ed...John Wiley \& Sons, USA, p.535.

8. Detay, M. 1997. Water wells implementation, maintenance and restoration, John Wiley \&Sons, London, $379 \mathrm{p}$.

9. Heath, R.C. 1983. Basic groundwater hydrology, U.S. Geological survey, water supply paper, 220$86 \mathrm{p}$.

10. World Health Organization (WHO), 2004. Guidelines for drinking water Quality, 4rd ed., Vol.1, Geneva, 564p. 
11. Karanta, K.R. 2008. Groundwater assessment development and management $12^{\text {th }}$ ed. McGrawHill publishing company limited .New York, p.217-275.

12. Tood, D.K. 1980. Groundwater hydrology $2^{\text {nd }}$ ed., John Wiley \&Sons, Inc. New York.535p.

13. Tood, D.K. 2007. Groundwater hydrology $2^{\text {nd }}$ ed. John Wiley \&Sons, USA, p535.

14. Boyd, C.E. 2000. Water Quality .An introduction .Kluwer Acad. Publisher, USA, p. 330.

15. Davis, S.N. and De Wiest, R.J.M. 1966. Hydrogeology .John Wiley \& Sons, New York, 463p.

16. Grases, F.; Perllo, J.; Isern, B. \&Costa -Bauza, A. 2007. Myo inositol hexkis phosphate (phytate) in hibits calcium carbonate crystallization in hard water .Water SA.5(33): 749 -754.

17. World Health Organization (WHO), 2009. Calcium and magnesium in drinking water public health significance. Geneva, Spain. P.165.

18. Foster, M.D. 1942. Base Exchange and sulfate reduction salty groundwater along Atlantic and Gulf Costs. AM. Assoc. Petroleum geologists Bull., 26: 838-851.

19. Guidelines for Canadian drinking water quality (GCDWQ), 2007. Chemical analysis interpretation of domestic farm water supplies. WWW.agric. gov. ab. Ca/app84/rwqit. 1-August 2007.

20. Dardka, K.1987. Groundwater hydrology, patriotism laboratory, Jordon, pp.430 (in Arabic).

21. Dally, D. 1994. Chemical pollution in groundwater; a Review of the situation in Ireland .Conf."Chemicals a cause for Cocern"Cork, 1994.

22. Hem, J.D. 1985. Study and interpretation of the chemical characteristics of natural water, 3rd ed. U.S.G.S. water supply paper .2254-263p.

23. Sawyer, C. \& Mecarty, P.L. 1985. Chemistry of environmental engineering $.3^{\text {rd }}$ ed. McGraw-Hill book VSA.

24. Iraqi standard (IQS), 2009. Iraqi standard of drinking water, No.417.modification No.2.

25. World Health Organization (WHO), 2007. Guidelines for drinking water quality $3^{\text {th }}$ ed., VOL.1-1 Recommendation, Geneva, p.595.

26. Ljungberg, V. 2004. Assessment of groundwater flow and pollutant transport through modeling .M.Sc. Science, Stockholm .Sweden 110p.

27. Hudak, P.F. 2000. Principles of Hydrogeology $.2^{\text {nd }}$ ed., Lewis, New York, 204p.

28. AL Badri, A.S. and AL Ameri, M.A. 2004. Hydro chemical study and Nitrate pollution of groundwater in the area of samarra- himreen, Ministry of water resources, G.D.F. water well drilling. (In Arabic).62 p.

29. Landschoot, P. 2007. Irrigation water quality, Guidelines for Turfgrass sites ,College of agricultural sciences ,the Pennsylvania state university ,USA, http:// turfgrass management .Psu.edu./ irrigation water quality for turfgrass. CFM.

30. Hem, J.D. 1989. Study and interpretation of the chemical characteristics of natural water U.S. geological survey, water supply paper 2254-246p.

31. Ivanov, V.V. 1968. The main genetic type of the earth crust mineral water and their distribution in the USSR .Inter. Ge of $23^{\text {rd }}$ sessions czehoslovakia, VOL.12, 33p.

32. Adams, S.; Titus, R.; Pieterson, K.; Tredoux, G. and Harris, C. 2001. Hydro chemical characteristic of aquifers near Suther land in the western Karoo, South Africa, J. Hydrogeology 24: 91-103.

33. Rhoades, J.D. 1982. Cation exchange capacity. In: A.L. page(ed.) Methods of soil analysis. Part 2: chemical and microbiological properties , $2^{\text {nd }}$ ed., Agronomy No.9,pp:149-157.

34. Van Hoorn, J.W. 1970. Quality of irrigation water ,limits of use and prediction of long term effects, salinity seminar Baghdad, irrigation and drainage paper No.7, FAO, pp.117-135.

35. Eaton, F.M. 1950. Significance of carbonate in irrigation water, soil science, No.69, pp.123-126.

36. Subramain, T.; Elango, L. and Damodarasamy, S.R. 2005. Groundwater Quality and it is suitability for drinking and agriculture use in chithar river basin, Tamil Nadu, India. Environ. Geol., 47: 1099-1110.

37. Karanth, K.R. 2008. Groundwater assessment development and management, Tata Mc Graw Hill offices Newdalhy. p.720.

38. Altoviski, M.E. 1962. Handbook of hydrogeology, Gosgoelitzdat, Moscow USSR.614p. 